\title{
PROTECTIVE ACTIVITY OF ASCORBIC ACID AT INFLUENZA INFECTION
}

\author{
V.V. Zarubaev ${ }^{a}$, A.V. Slita ${ }^{a}$, I.N. Lavrentyeva ${ }^{a}$, V.S. Smirnov \\ ${ }^{a}$ St. Petersburg Pasteur Institute, St. Petersburg, Russian Federation \\ ${ }^{b}$ Cytomed, Ltd., St. Petersburg, Russian Federation
}

\begin{abstract}
Ascorbic acid (vitamin C, AA) is an essential nutrient of the human diet due to its participation on numerous regulatory and enzymatic processes. AA takes part in such vital physiological processes as hormone production, collagen synthesis, stimulation of the immune system, etc. In the present review the activities of AA are considered that provide its protective effect at influenza infection. This effect can be result of direct virus-inhibiting activity of AA as well as of anti-inflammatory and antioxidant properties. Oxidative stress during influenza infection leads to nonspecific damage of the pulmonary tissue and subsequent inflammation of the lungs. The antioxidant activity of AA results in alleviation of infection due to suppression of tissue damage as well as in inhibition of reactive oxygen species-mediated signal transduction and regulatory reactions. After oxidation by ROS, AA is converted to dehydroascorbic acid (DAA) and inhibits the key enzymes of NF- $\mathrm{kB}$ pathway, such as kinases IKK $\alpha$ and IKK $\beta$. AA itself blocks the activity of another component of the NF-kB pathway, kinase $\mathrm{IKK} \beta(\mathrm{SS} / \mathrm{EE})$, whose activity is directed to the phosphorylation of the factor $\mathrm{I} \kappa \mathrm{B} \alpha$. As a result, activation of NF- $\kappa \mathrm{B}$ and its transport to the nucleus does not occur. Thus, AA performs a dual function: first, it neutralizes free radicals, preventing them from activating NF- $\mathrm{KB}$, and secondly, the product of its oxidation, DAA, further blocks the activation of this pathway. In addition, in some cases AA results in the decrease in the infectious activity of influenza virus that is not due to the antioxidant activity of AA, but to direct virus-inhibiting activity. Taken together, the presented data suggests that the use of drugs with antiviral and antioxidant activity, as a combination of individual drugs or, as in the case of AA, as a single drug with complex activity, for treatment of influenza has advantages over the etiotropic drug monotherapy scheme.
\end{abstract}

Key words: vitamin C, ascorbic acid, influenza, antivirals, anti-inflammatory activity, antioxidant activity.

\section{ПРОТЕКТИВНАЯ АКТИВНОСТЬ АСКОРБИНОВОЙ КИСЛОТЫ ПРИ ГРИППОЗНОЙ ИНФЕКЦИИ}

Зарубаев В.В. ${ }^{,}$, Слита А.В. ${ }^{1}$, Лаврентьева И.Н. ${ }^{1}$, Смирнов В.С. ${ }^{2}$

${ }^{1}$ ФБУН НИИ эпидемиологии и микробиологии имени Пастера, Санкт-Петербург, Россия

2 ЗАО «Цитомед», Санкт-Петербург, Россия

Резюме. Аскорбиновая кислота (витамин С, АК) является важным пищевым компонентом для человека благодаря ее роли в различных регуляторных и ферментативных процессах. АК принимает участие в таких жизненно важных физиологических процессах, как продукция гормонов, синтез коллагена, стимуляция иммунной системы и пр. В настоящем обзоре рассмотрена активность АК, обеспечивающая ее протективный эффект при гриппозной инфекции. Этот эффект может быть обусловлен прямой вирусингибирующей активностью АК, а также ее противовоспалительными и антиоксидантными свойствами. Окислительный стресс при гриппе ведет к неспецифическому повреждению ткани легких и развитию воспаления. Антиоксидантная активность АК приводит к облегчению течения инфекции вследствие снижения уровня повреждения ткани и ингибиро-

\author{
Адрес для переписки: \\ Зарубаев Владимир Викторович \\ 197101, Россия, Санкт-Петербург, ул. Мира, 14, \\ ФБУН НИИ эпидемиологии и микробиологии имени Пастера. \\ Тел.: 8 911 928-04-95 (моб.). \\ E-mail: zarubaev@gmail.com
}

\author{
Contacts: \\ Vladimir V. Zarubaev \\ 197101, Russian Federation, St. Petersburg, Mira str., 14, \\ St. Petersburg Pasteur Institute. \\ Phone: +7 911 928-04-95 (mobile). \\ E-mail: zarubaev@gmail.com
}

\section{Citation:}

Zarubaev V.V., Slita A.V., Lavrentyeva I.N., Smirnov V.S. Protective activity of ascorbic acid at influenza infection // Russian Journal of Infection and Immunity = Infektsiya i immunitet, 2017, vol. 7, no. 4, pp. 319-326. doi: $10.15789 / 2220-7619-2017-4-319-326$

\begin{abstract}
Зарубаев В.В., Слита А.В., Лаврентьева И.Н., Смирнов В.С.
Протективная активность аскорбиновой кислоты при гриппозной

инфекции // Инфекция и иммунитет. 2017. Т. 7, № 4. С. 319-326.

doi: 10.15789/2220-7619-2017-4-319-326
\end{abstract}


вания передачи сигнала и регуляторных реакций, опосредуемых активными формами кислорода (АФК). После окисления АФК АК превращается в дегидроаскорбиновую кислоту (ДАК) и ингибирует ключевые ферменты сигнального пути NF-кB, такие как киназы IKK $\alpha$ и IKK $\beta$. Сама АК блокирует активность другого компонента пути NF-кB - киназу IKK $\beta(\mathrm{SS} / \mathrm{EE})$, активность которой направлена на фосфорилирование фактора ІкВ $\alpha$. В результате активации NF-кB и его транспорта в ядро не происходит. Таким образом, АК осуществляет двойную функцию: во-первых, нейтрализует свободные радикалы, предотвращая активацию ими NF-кB, и, во-вторых, продукт ее окисления, ДАК, дополнительно блокирует активацию этого сигнального пути. Кроме того, в некоторых случаях АК приводит к снижению инфекционной активности вируса, что обусловлено не антиоксидантными свойствами АК, а ее прямой противовирусной активностью. Вместе взятые, представленные данные свидетельствуют, что использование препаратов с противовирусной и антиоксидантной активностью как в виде комбинации, так и, как в случае с АК, в виде единого препарата с комплексной активностью, для лечения гриппа имеет преимущества перед этиотропной схемой лечения гриппа монопрепаратами.

Ключевые слова: витамин С, аскорбиновая кислота, грипп, противовирусные препараты, противовоспалительная активность, антиоксидантная активность.

Ascorbic acid (vitamin C, AA, Fig.) is an important nutrient of the human diet, since it is not synthesized in the human body, similarly to guinea pigs and most primates. Other mammals (about 4000 species) are able to produce AA in the amount of about $50 \mathrm{mg} / \mathrm{kg}$ of body weight per day, or, in terms of human body, $5 \mathrm{~g} /$ day. This dose is sufficient to ensure the normal functioning of the body and resistance to infections [64].

Being a potent antioxidant $[37,46]$ and cofactor of many enzymes, AA takes part in such vital physiological processes as hormone production, collagen synthesis [6], stimulation of the immune system [16, $45,63]$, etc. The long-term lack of vitamin $\mathrm{C}$ leads to scurvy, a pathological process caused primarily by a violation of collagen production and manifested in the destruction of blood vessels, disorders in the formation of bone tissue and attachment of the periosteum to the bones as well as loosening of teeth $[21,40]$. In addition, a decrease in the level of collagen leads to a violation of the architectonics of the lung tissue, which causes primary pneumonia or provokes the development of secondary ones, which are the leading complication and the main cause of death in scurvy [28]. For many years, vitamin C has been considered as a key factor in the development of scurvy - a pathology of connective tissue. Indeed, in addition to the described symptoms, patients suffer from wound healing disorders and other pathologies that can be explained from this point of view. Therefore, the role of vitamin $\mathrm{C}$ was mainly, if not exclusively, attributed to the maintenance of the integrity of the connective tissue, despite numerous observations of the effect of AA on the course of infectious processes as well [25].

Along with this, however, ascorbic acid has a range of other biological activities. In particular, it is shown that it plays an important role in epigenetic regulation, being in the form of ascorbate anion a co-factor of methylcytosine dioxygenase, an enzyme responsible for DNA demethylation. In addition, AA is also a cofactor of enzymes that carry out methylation of histones, which also provides epigenetic regulation of gene activity, in particular by changing the concentration and bioavailability of AA in different sites of organs and tissues. This activity is important in the development of pathologies such as neurodegenerative and oncological diseases in the absence of AA [10].

Among many types of biological activity of AA, its ability to inhibit the reproduction of viruses from a wide variety of families and phylogenetic groups should be specially noted. In the XIX-XX centuries, AA was used to treat hepatitis, encephalitis, influenza, SARS and some other viral infections. In 1970, Pauling's book «Vitamin C and Common Cold» was published, where a favorable effect of high doses of AA as a mean of preventing and treating ARI was proved [47].

The effect of AA on the course of a viral infection can be explained by several factors. First, being an antioxidant, AA has a neutralizing effect on one of the leading factors of the pathogenesis of a viral infection - the free radicals formed by inflammation and the oxidative stress caused by them. Secondly, many viruses use free radicals as regulators of their own reproduction and signaling cascades during the viral cycle. The inhibition of the formation of free radicals using AA, therefore, has an indirect inhibitory effect on the replication and spread of viruses. Finally, AA, in some cases, acts independently of antioxidant activity, suppressing viral reproduction directly, i.e. as an etiotropic agent, albeit of low efficiency.

Below we describe each of the mechanisms of AA activity in viral infections separately. Prior to describing the activity of AA in viral pathology, we will consider the pathological process itself in terms of balance between pro- and antioxidant factors.

The term «free radicals» (FR) means molecules containing one or more unpaired electrons at the upper electronic level, as well as molecules that possess high reactivity in biological systems and in the absence of such unpaired electrons. Examples of FR include molecular oxygen $\mathrm{O}_{2}$, superoxide radical $\mathrm{O}_{2}{ }^{\bullet-}$, hydroxyl radical $\mathrm{OH}^{-}$, nitrogen oxide $\mathrm{NO}$, hydrogen peroxide $\mathrm{H}_{2} \mathrm{O}_{2}$, peroxynitrite $\mathrm{ONOO}^{-}$, etc. reactive 
oxygen species (ROS) and active forms of nitrogen (AFN) are produced both in normal physiological conditions, and in pathological ones. Among them, $\mathrm{O}_{2}$ and $\mathrm{NO}$ are the key intermediates in infectious processes. They play an important role in the transfer of intercellular signal transduction, the regulation of cytokine production, growth and transcription factors, immunomodulation and apoptosis processes, etc. [11].

However, many pathogens in the course of the infectious process lead to the activation of phagocytes and neutrophils, which produce ROS, which is accompanied by the production of excessive FR. In organism, ROS serve to inactivate viruses, destroy bacteria and remove cell decay products, as well as regulate apoptosis, i.e. to normalize the state of the organism, eliminate pathogens and maintain homeostasis. However, with the propagation of the pathogen, more FR is produced, which leads to a shift in the redox balance. In view of their low selectivity, ROS are one of the main factors in the pathogenesis of many acute infections, resulting in DNA damage, lipids and proteins destruction, loss of integrity of healthy cells, excessive and inadequate damage to the tissue architectonics and functions of the target organ [1, 48]. In addition, under such conditions, transcription factors such as $\mathrm{NF}-\kappa \mathrm{B}$, which in some cases are proviral [55], are activated, as we will discuss below. The suppression of these processes, therefore, should be considered as a method of protecting tissue in the foci of inflammation and general protection in the course of infectious processes. To maintain a balance between oxidative and antioxidant processes in the tissue, there is an antioxidant defense system, represented by an enzymatic and non-enzymatic species. The first include enzymes of metabolism of ROS, like catalase, glutathione peroxidase and superoxide dismutase, neutralizing, in particular, $\mathrm{O}_{2}{ }^{--}$and $\mathrm{H}_{2} \mathrm{O}_{2}$. The second group is represented by organic antioxidants vitamins $\mathrm{C}$ and $\mathrm{E}$, polyphenols, carotenoids, etc.

\section{Suppression of virus reproduction due to antioxidant activity}

The disturbance of the oxidant-antioxidant balance leads to oxidative stress, the formation of which has been proved today for the vast majority of acute viral infections. This was first shown for the Sendai virus model and mouse splenocytes, which enhance the production of FR in response to contact with the virus, not only intact, but also inactivated by ultraviolet irradiation [49]. Later the increase of oxidative activity in cells leading to their death was shown for many viruses, both RNA and DNA genomic [44, $50,52]$.

FR and lipid peroxidation products affect the reproduction of viruses by regulating cell activity, the inflammatory and immune response in general, as well as damaging the components of the virus and the host cell. Destruction of infected and neighboring target cells can limit the spread of the virus. However, in general, it is not completely understood how much the benefit of such destruction exceeds, if at does, its negative consequences. Thus, it is known that oxidative stress promotes the replication of RNA-genome alpha- and flaviviruses [20], and that the use of antioxidants significantly inhibits this process by violating the capping of virus-specific mRNAs. Similarly, oxidative stress contributes to the reproduction of human papillomavirus at several stages [62]. Data on the hepatitis $\mathrm{C}$ virus, however, are contradictory: there is evidence of both the inhibitory effect of oxidative stress on viral reproduction and the inhibitory properties of antioxidants [11].

Viruses affect the oxidant-antioxidant balance of the host, increasing the concentration of oxidizing components (peroxides and nitric oxide) and reducing the production of antioxidant enzymes such as SOD, catalase, etc. Thus, oxidative stress affects various aspects of the pathogenesis of viral infections, and the use of antioxidants also can affect the course of the virus-induced pathological process by different ways.

\section{Protective activity in tissue and pathogenetic activity}

Oxidative stress during influenza infection leads to nonspecific damage of the pulmonary tissue and subsequent inflammation of the lungs [2, 13]. FR, such as a peroxide radical and nitric oxide, are released into the extracellular space by inflammatory cells (activated neutrophils, producing an order of magnitude greater FR than resting neutrophils) and respiratory epithelial cells. Accumulation of neutrophils in the alveoli leads to the accumulation of FR, proteases and products of lipid peroxidation. Damage of pulmonary tissue at influenza is thus provided by two mechanisms - direct viral cytotoxicity and toxic effects in case of excessive inflammation. Obviously, the last of these mechanisms can be neutralized with antioxidants. Among the compounds of this group, AA is optimal because of its effectiveness, low toxicity, high solubility and bioavailability, and higher stability compared to, for example, glutathione.<smiles>O=C1OC(C(O)CO)=C(O)C1O</smiles>

Figure. Ascorbic acid 
Hennet T. et al. have shown that concentration of the main antioxidants, glutathione and vitamins $\mathrm{C}$ and $\mathrm{E}$, decreases in blood plasma, lungs and liver after influenza infecting [27]. This phenomenon increases the susceptibility of the organism to other damaging factors, not necessarily even of an infectious nature.

The effect of glutathione on the course of influenza infection in cell culture was also studied [8]. As a result of the experiments, it was shown that in the presence of glutathione, the infectious activity of the virus, as well as the expression of the M1 virus protein and the activity of apoptotic processes, the virus-induced activation of proapoptotic caspase (caspase 3 ), were decreased. This was accompanied by inhibition of virus-induced activation of the surface «death receptor» Fas.

Introduction of glutathione into drinking water of influenza-infected mice was shown to inhibit production of the virus in lung tissue and trachea, suggesting the proviral role of oxidative processes in the tissues in the course of influenza infection. The damaging effects of innate immune factors such as inflammatory cytokines, TLR-4 and TLR-7, NF$\kappa \mathrm{B}$, as well as the level of tissue infiltration of inflammatory cells in influenza could be prevented by an antioxidant catalase enzyme [56].

Thus, the disturbance of the oxidation-antioxidant balance in influenza infection plays a dual role in the pathogenesis of influenza. On the one hand, an increase in the concentration of FR leads to nonspecific damage to the target tissue. On the other hand, it contributes to the reproduction of the virus, which further activates the infectious process.

It is known that influenza infection in mice leads to a decrease in vitamin $\mathrm{C}$ content in bronchopulmonary lavage [7], and vitamin $C$ deficiency leads to a significant increase in the degree of lung pathology [38]. Similarly, infection with the respiratory syncytial virus leads to a decrease in the production of antioxidant enzymes and, as a consequence, to an increase in the oxidative damage of cells in the respiratory system [29].

An increase in the level of oxidative processes during infection explains the decrease in the level of AA as a compound, primarily exposed to ROS. For example, in the plasma of patients with symptoms of acute respiratory viral infection, the AA content is half that of normal people and returns to normal after recovery. It was shown that a decrease in the level of AA in acute respiratory viral infections (ARVI) can be neutralized by taking $6 \mathrm{~g}$ of vitamin $\mathrm{C}$ per day [31].

Possible mechanisms of action of AA at influenza have been studied by Cai Y. et al. [9]. It is known that at the level of the whole organism influenza infection leads to stress that is accompanied by the production of glucocorticoid hormones. Their increased amount leads to increase in the level of lipid peroxidation and the release of ROS from the mitochondria. It is shown that AA inhibits both the synthesis of glucocorticoids themselves and the intensity of oxidative processes induced by them, thereby reducing the susceptibility of animals to influenza under stress.

On the model of liver immune damage [39], it was shown that the use of AA significantly reduces the level of the main inflammatory mediators - IFN $\gamma$, IL-4, IL-6, IL-8, TNF $\alpha$, as well as inflammatory factors such as cyclooxygenase COX-2 and inducible NO-synthetase iNOS and $\mathrm{NF}-\kappa \mathrm{B}$. Given that all of these factors are universal mediators of inflammation, it can be assumed that in the case of influenza infection this mechanism of AA activity also takes place.

In addition to the protective activity of AA due to its antioxidant properties, this vitamin $\mathrm{C}$ possesses the properties of immunomodulator. First of all, it concerns the factors of innate immunity, which drive the development of inflammatory reaction. For example, important data on the mechanism of AA activity were obtained by Tan P.H. et al. [58]. It has been demonstrated that the AA treatment significantly affects the properties of dendritic cells reducing their sensitivity to pro-inflammatory cytokines. Moreover, acting as regulatory factors, such cells induce anergy in T cells, making them tolerant to antigenic stimulation.

Similar results were obtained in the course of analysis of the production of inflammatory factors after stimulation of neural cells in culture [30]. Incubation with bacterial lipopolysaccharide led to the activation of the synthesis of nitric oxide and the expression of inflammatory mediators - iNOS, IL-6 and MIP-2, and also suppressed the nuclear translocation of the main inflammatory trigger factor $\mathrm{NF}-\kappa \mathrm{B}$. In cells of endothelial origin, AA inhibited the activation of $\mathrm{NF}-\kappa \mathrm{B}$ in response to various stimuli, such as IL-1 and TNF. It is important that along with redoxdependent signal transduction systems, treatment with ascorbic acid also inhibited redox-independent pathways of $N F-\kappa B$ activation. Detailed studies for identifying a specific AA target allowed to establish that MAP-kinase p38 [5] is affected, at least by high concentrations of AA. Using gene-knockout mice defective in the Gulo gene, which provides the biosynthesis of AA in mice, Bae S. et al. [3] showed that, at toxic liver damage, the levels of proinflammatory cytokines (TNF $\alpha$ and IFN $\gamma$ ), as well as the intensity of apoptosis of hepatocytes and inflammatory liver infiltration, were significantly increased in these mice compared to controls. When infected with the influenza virus, despite the same level of reproduction of the virus in the lungs comparing to control animals, they demonstrated much advanced lung tissue damage and increased levels of influenza-specific cytokines, such as RANTES, IL-1 $\beta$ and TNF $\alpha$, as well as the factor NF$\kappa \mathrm{B}$, on early stages of the disease. In contrast, on late stages the levels of RANTES, MCP-1 and IL-12 were lower than in control mice [38]. In another similar 
study [36], it was shown that viral activity in the lung tissue of Gulo (-/-) mice was increased in the absence of AA, and the production of the antiviral cytokine IFN $\alpha / \beta$ was lower than in animals receiving AA. The level of cellular infiltration and the production of pro-inflammatory cytokines, such as TNF $\alpha$ and IL- $1 \alpha / \beta$ in lung tissue, were increased. In general, the results obtained indicate that vitamin $C$ provides an antiviral immune response in vivo by activating the synthesis of IFN $\alpha / \beta$.

Special attention should be paid to the influence of AA on the key components of inflammation. Thus, ROS along with pro-inflammatory cytokines ( TNF $\alpha$ ), hydrogen peroxide and many other factors activate the transcription factor $\mathrm{NF}-\mathrm{kB}$, which plays an important role in cell defense, inflammation and apoptosis [4]. In inactive form, NF-kB is bound to the regulatory protein $\mathrm{I} \kappa \mathrm{B}$ and localized in the cytoplasm. These factors activate the cellular kinases IKK $\alpha$ and IKK $\beta$, which carry out the phosphorylation of $\mathrm{I} \kappa \mathrm{B}$. After phosphorylation it dissociates from NF-kB and degrades in proteasomes, whereas $\mathrm{NF}-\mathrm{kB}$ itself in free form can be translocated from the cytoplasm into the cell nucleus where it activates the genes of the inflammatory cascade.

Important data were obtained by studying the role of AA in this process. After oxidation in reaction with ROS, AA is converted to dehydroascorbic acid (DAA). It was shown that DAA inhibits the key enzymes of $\mathrm{NF}-\kappa \mathrm{B}$ pathway, such as kinases IKK $\alpha$ and IKK $\beta$, whereas the AA itself does not possess this ability. AA, however, blocked the activity of another component of the NF-kB pathway, kinase IKK $\beta$ (SS/ EE), whose activity is directed to the phosphorylation of the factor $\mathrm{I} \kappa \mathrm{B} \alpha$. Importantly, the inhibition of IKK $\alpha$ and IKK $\beta$ kinase activity by DAA is specific, since the activity of, for example, p38 MAP kinase, was only slightly reduced in the presence of very high DAA concentration $(0.5 \mathrm{mM})$. As a result of inhibition of IKK $\alpha$ and IKK $\beta$ kinases, activation of $\mathrm{NF}-\kappa \mathrm{B}$ and its transport to the nucleus does not occur. Thus, AA performs a dual function: first, it neutralizes free radicals, preventing them from activating $\mathrm{NF}-\kappa \mathrm{B}$, and secondly, the product of its oxidation, DAA, further blocks the activation of this pathway. It is believed that the suppression of the enzymatic activity of kinases occurs when the DAA is linked to their active sites and the binding or catalysis is blocked with ATP or substrate, since the addition of excess of ATP partially removed the inhibitory effect of DAA [12]. Thus, the effect of AA is based on the inhibition of kinase processes regulating the activity of the main signaling pathway of inflammation $\mathrm{NF}-\kappa \mathrm{B}$.

Another mechanism of protective activity of AA in inflammation was studied on the model of sepsis in Gulo (-/-) mice. It is known that one of the mechanisms of pathogens inactivation in the body is the formation of so-called neutrophil extracellular traps (NET), when DNA released from destroyed neutrophils binds virus particles and bacterial cells. The number of such traps in mice incapable of synthesizing AA was significantly higher in sepsis than in control animals. Other sepsis-specific processes in neutrophils, such as autophagy, endoplasmic stress, histone modification, were also activated. All these indicators, however, returned to normal values after AA application [43].

In a patient with acute respiratory distress syndrome, signs of pathology were removed by intravenous administration of high dose vitamin C, $200 \mathrm{mg} /$ $\mathrm{kg} /$ day [17]. Similarly, the pain syndrome and the inflammatory response in a patient with Chikungunya fever [19] were eliminated for 2 days. Taken together, the above data indicate the important role of AA as a regulator of the inflammatory process in the body.

Concerning the use of AA at influenza, it should be said that several studies suggest that the suppression of viral reproduction requires its relatively high concentration $(5 \mathrm{mM})$, which in terms of the human body is about 4.4 grams per day. Obviously, the doses used do not allow this mechanism of activity to be realized. To increase the efficiency of absorption and taking into account that the dose of AA higher than $1 \mathrm{~g} /$ day can lead to side effects, for the therapeutic effect is recommended not oral but intravenous route of administration. At the same time, a sharp abolition of AA after therapy can mimic its deficiency and lead, therefore, to the development of scurvy symptoms. All this should be considered when prescribing vitamin $\mathrm{C}$ for the purpose of treating the flu. Nevertheless, the available data indicate the undoubted therapeutic effect of AA as a means of minimizing cell death - one of the leading pathogenetic factors in influenza, including highly pathogenic avian influenza H5N1 [64].

\section{Direct antiviral activity of ascorbic acid}

Speaking about the direct antiviral effect of AA, first of all human immunodeficiency virus should be mentioned. It is shown that clinical effectiveness of antiretroviral therapy rises sharply with AA consumption. It is important that AA in this case does not work as a specific antiviral drug, but inhibits viral reproduction due to its antioxidant properties inhibiting ROS that play an essential role in signal transducion and control of gene expression [24, 41]. Suppression of HIV replication occurs through transcription factors NF- $\mathrm{B}$, AP-1 and USF, whose activity is suppressed by antioxidants [22, 32, 53]. Nevertheless, there is evidence that AA suppresses reproduction of HIV directly by blocking the regulation of viral reproduction at the stage of Tat-dependent elongation of the viral genome. It was shown that the degree of this suppression was not accompanied by a decrease in the activity of the main transcription factors - RNA polymerase II, NF- $\kappa \mathrm{B}, \mathrm{S}-1$ and USF factors [23]. 
It was also shown that the intravenous use of AA in patients infected with the Epstein-Barr virus led to a decrease in the duration of the disease, as well as an increase in the titer of specific antibodies [42].

As early as 1978 , clinical tests demonstrated that using high doses of vitamin C (1 g per day) in combination with bioflavonoids, the duration of pain caused by herpes infection (herpes labialis) decreased from 3.1 to 1.3 days. Moreover, with the onset of AA administration 24 hours after the onset of symptoms of herpes, only 6 of 26 patients $(23 \%)$ reported the development of specific vesicles, whereas at the late start of treatment they were formed in 8 of 12 patients (67\%). Obtained results, of course, do not directly indicate the role of AA, since flavonoids were involved in the study. No evidence exists, nevertheless, of their effect on herpetic infection, so the described clinical effect might be attributed to vitamin $\mathrm{C}$.

In cell cultures, ascorbic acid suppresses the reproduction of the influenza virus [34]. At the same time, its reduced form, dehydroascorbic acid, which does not exhibit antioxidant properties, exhibits much higher antiviral activity compared to AA. Consequently, as in the described case with HIV, the decrease in the infectious activity of the virus is not due to the antioxidant activity of AA, but to other characteristics [18].
In clinical trials involving 226 patients diagnosed with influenza A, the effect of AA on the incidence of complications in the form of pneumonia and the length of stay in the hospital were studied. Among the control group, 10 of 112 patients developed pneumonia, whereas among patients receiving $300 \mathrm{mg}$ of AA daily, only 2 out of 114 . The length of stay in the hospital was 12 days in the control group and 9 days in the experimental group. Thus, the use of AA contributes to reducing the severity of influenza in patients (Banerjee, 2010).

In general, the use of AA at influenza has been the subject of active study and discussion for 70 years [26]. The latest Cochrane review of the effectiveness of the use of AA in respiratory pathologies of about 11 thousand people did not reveal significant differences between the control and the experimental group in terms of the incidence rate. Nevertheless, it has been shown that the systematic use of vitamin $C$, although not in all the clinical studies reviewed, reduces the duration and severity of common cold symptoms.

In conclusion, the use of drugs with antiviral and antioxidant activity, as a combination of individual drugs or, as in the case of AA, as a single drug with complex activity, for treatment of influenza has advantages over the etiotropic drug monotherapy scheme [60].

\section{References}

1. Akaike T. Role of free radicals in viral pathogenesis and mutation. Rev. Med. Virol., 2001, vol. 11, iss. 2, pp. 87-101. doi: 10.1002/rmv.303

2. Akaike T., Noguchi Y., Ijiri S., Setoguchi K., Suga M., Zheng Y.M., Dietzschold B., Maeda H. Pathogenesis of influenza virus-induced pneumonia: involvement of both nitric oxide and oxygen radicals. Proc. Natl. Acad. Sci. USA, 1996, vol. 93, no. 6, pp. $2448-2453$

3. Bae S., Cho C.H., Kim H., Kim Y., Kim H.R., Hwang Y.I., Yoon J.H., Kang J.S., Lee W.J. In vivo consequence of vitamin C insufficiency in liver injury: vitamin C ameliorates T-cell-mediated acute liver injury in Gulo (-/-) mice. Antioxid. Redox Signal., 2013, vol. 19, iss. 17, pp. 2040-2053. doi: 10.1089/ars.2012.4756

4. Baeuerle P.A., Henkel T. Function and activation of NF-kB in the immune system. Annu. Rev. Immunol., 1994, vol. 12, pp. 141-179. doi: 10.1146/annurev.iy.12.040194.001041

5. Bowie A.G., O'Neill L.A. Vitamin C inhibits NF-kappa B activation by TNF via the activation of $\mathrm{p} 38$ mitogen-activated protein kinase. J. Immunol., 2000, vol. 165, iss. 12, pp. 7180-7188. doi: https://doi.org/10.4049/jimmunol.165.12.7180

6. Boyera N., Galey I., Bernard B.A. Effect of vitamin C and its derivatives on collagen synthesis and cross-linking by normal human fibroblasts. Int. J. Cosmet. Sci., 1998, vol. 20, iss. 3, pp. 151-158. doi: 10.1046/j.1467-2494.1998.171747.x

7. Buffinton G.D., Christen S., Peterhans E., Stocker R. Oxidative stress in lungs of mice infected with influenza A virus. Free Radic. Res. Commun., 1992, vol. 16, iss. 2, pp. 99-110. doi: 10.3109/10715769209049163

8. Cai J., Chen Y., Seth S., Furukawa S., Compans R.W., Jones D.P. Inhibition of influenza infection by glutathione. Free Radic. Biol. Med., 2003, vol. 34, iss. 7, pp. 928-936. doi: 10.1016/S0891-5849(03)00023-6

9. Cai Y., Li Y.F., Tang L.P., Tsoi B., Chen M., Chen H., Chen X.M., Tan R.R., Kurihara H., He R.R. A new mechanism of vitamin $\mathrm{C}$ effects on A/FM/1/47(H1N1) virus-induced pneumonia in restraint-stressed mice. Biomed Res. Int., 2015, vol. 2015 , 12 p. doi: $10.1155 / 2015 / 675149$

10. Camarena V., Wang G. The epigenetic role of vitamin C in health and disease. Cell. Mol. Life Sci., 2016, vol. 73, iss. 8, pp. 1645-1658. doi: $10.1007 / s 00018-016-2145-x$

11. Camini F.C., da Silva Caetano C.C., Almeida L.T., de Brito Magalhães C.L. Implications of oxidative stress on viral pathogenesis. Arch. Virol., 2017, vol. 162, iss. 4, pp. 907-917. doi: 10.1007/s00705-016-3187-y

12. Cárcamo J.M., Pedraza A., Bórquez-Ojeda O., Zhang B., Sanchez R., Golde D.W. Vitamin C is a kinase inhibitor: dehydroascorbic acid inhibits IкB $\alpha$ kinase $\beta$. Mol. Cell. Biol., 2004, vol. 24, no. 15, pp. 6645-6652. doi: 10.1128/mcb.24.15.6645-6652.2004

13. Choi A.M., Knobil K., Otterbein S.L., Eastman D.A., Jacoby D.B. Oxidant stress responses in influenza virus pneumonia: gene expression and transcription factor activation. Am. J. Physiol., 1996, vol. 271, no. 3, pp. L383-L391.

14. Coates B.M., Staricha K.L., Wiese K.M., Ridge K.M. Influenza A virus infection, innate immunity, and childhood. JAMA Pediatr., 2015, vol. 169, no. 10, pp. 956-963. doi: 10.1001/jamapediatrics.2015.1387

15. Hemilä H., Chalker E., Douglas B. Vitamin C for preventing and treating the common cold. Cochrane Database Syst. Rev., 2007, no. 3, CD000980. doi: 10.1002/14651858.CD000980.pub3 
16. Englard S., Seifter S. The biochemical functions of ascorbic acid. Ann. Rev. Nutr., 1986, vol. 6, pp. 365-406. doi: 10.1146/annurev. nu.06.070186.002053

17. Fowler III A.A., Kim C., Lepler L., Malhotra R., Debesa O., Natarajan R., Fisher B.J., Syed A., DeWilde C., Priday A., Kasirajan $\mathrm{V}$. Intravenous vitamin $\mathrm{C}$ as adjunctive therapy for enterovirus/rhinovirus induced acute respiratory distress syndrome. World J. Crit. Care Med., 2017, vol. 6, iss. 1, pp. 85-90. doi: 10.5492/wjccm.v6.i1.85

18. Furuya A., Uozaki M., Yamasaki H., Arakawa T., Arita M., Koyama A.H. Antiviral effects of ascorbic and dehydroascorbic acids in vitro. Int. J. Mol. Med., 2008, vol. 22, iss. 4, pp. 541-545. doi: 10.3892/ijmm_00000053

19. Gonzalez M.J., Miranda-Massari J.R., Berdiel M.J., Duconge J., Rodríguez-López J.L., Hunninghake R., Cobas-Rosario V.J. High dose intraveneous vitamin C and chikungunya fever: a case report. J. Orthomol. Med., 2014, vol. 29, iss. 4, pp. 154-156.

20. Gullberg R.C., Steel J.J., Moon S.L., Soltani E., Geiss B.J. Oxidative stress influences positive strand RNA virus genome synthesis and capping. Virology, 2015, vol. 475, pp. 219-229. doi: 10.1016/j.virol.2014.10.037

21. Hampl J.S., Taylor C.A., Johnston C.S. Vitamin C deficiency and depletion in the United States: the Third National Health and Nutrition Examination Survey, 1988 to 1994. Am. J. Public Health, 2004, vol. 94, no. 5, pp. 870-875. doi: 10.2105/ajph.94.5.870

22. Harakeh S., Jariwalla R.J. Comparative study of the anti-HIV activities of ascorbate and thiol-containing reducing agents in chronically HIV-infected cells. Am. J. Clin. Nutr., 1991, vol. 54, suppl. 6, pp. 1231S-1235S.

23. Hayashi T. Preventive effect of ascorbic acid against biological function of human immunodeficiency virus trans-activator of transcription. J. Intercult. Ethnopharmacol., 2016, vol. 5, iss. 2, pp. 205-209. doi: 10.5455/jice.20160316010322

24. Hayashi T., Ueno Y., Okamoto T. Oxidoreductive regulation of nuclear factor kappa B. Involvement of a cellular reducing catalyst thioredoxin. J. Biol. Chem., 1993, vol. 268, no. 15, pp. 11380-11388.

25. Hemilä H. Vitamin C and infections. Nutrients, 2017, vol. 9, iss. 4: 339. doi: 10.3390/nu9040339

26. Hemilä H., Chalker E. Vitamin C for preventing and treating the common cold. Cochrane Database Syst. Rev., 2013, iss. 1, CD000980. doi: 10.1002/14651858.CD000980.pub4

27. Hennet T., Peterhans E., Stocker R. Alterations in antioxidant defences in lung and liver of mice infected with influenza A virus. J. Gen. Virol., 1992, no. 73, pp. 39-46. doi: 10.1099/0022-1317-73-1-39

28. Hess A.F. Scurvy, Past and Present. Philadelphia, USA: J.B. Lippincott Company, Washington Sqvare Press, 1920,261 p.

29. Hosakote Y.M., Jantzi P.D., Esham D.L., Spratt H., Kurosky A., Casola A., Garofalo R.P. Viral-mediated inhibition of antioxidant enzymes contributes to the pathogenesis of severe respiratory syncytial virus bronchiolitis. Am. J. Respir. Crit. Care Med., 2011, vol. 183, no. 11, pp. 1550-1560. doi: 10.1164/rccm.201010-17550C

30. Huang Y.N., Lai C.C., Chiu C.T., Lin J.J., Wang J.Y. L-ascorbate attenuates the endotoxin-induced production of inflammatory mediators by inhibiting MAPK activation and NF-кB translocation in cortical neurons/glia Cocultures. PLoS One, 2014, vol. 9, iss. 7: e97276. doi: 10.1371/journal.pone.0097276

31. Hume R., Weyers E. Changes in leucocyte ascorbic acid during the common cold. Scott. Med. J., 1973, vol. 18, iss. 1, pp. 3-7. doi: 10.1177/003693307301800102

32. Israël N., Gougerot-Pocidalo M.A., Aillet F., Virelizier J.L. Redox status of cells influences constitutive or induced NF-kappa B translocation and HIV long terminal repeat activity in human T and monocytic cell lines. J. Immunol., 1992, vol. 149, iss. 10, pp. 3386-3393.

33. Iwasaki A., Pillai P.S. Innate immunity to influenza virus infection. Nat. Rev. Immunol., 2014, vol. 14, pp. 315-328. doi: 10.1038/ nri3665

34. Jariwalla R.J., Roomi M.W., Gangapurkar B., Kalinovsky T., Niedzwiecki A., Rath M. Suppression of influenza A virus nuclear antigen production and neuraminidase activity by a nutrient mixture containing ascorbic acid, green tea extract and amino acids. BioFactors, 2007, vol. 31, iss. 1, pp. 1-15. doi: 10.1002/biof.5520310101

35. Kim H., Jang M., Kim Y., Choi J., Jeon J., Kim J., Hwang Y.I., Kang J.S., Lee W.J. Red ginseng and vitamin C increase immune cell activity and decrease lung inflammation induced by influenza A virus/H1N1 infection. J. Pharm. Pharmacol., 2016, vol. 68, iss. 3, pp. 406-420. doi: 10.1111/jphp.12529

36. Kim Y., Kim H., Bae S., Choi J., Lim S.Y., Lee N., Kong J.M., Hwang Y.I., Kang J.S., Lee W.J. Vitamin C is an essential factor on the anti-viral immune responses through the production of interferon- $\alpha / \beta$ at the initial stage of influenza a virus (H3N2) infection. Immune Netw., 2013, vol. 13, no. 2, pp. 70-74. doi: 10.4110/in.2013.13.2.70

37. Kojo S. Vitamin C: basic metabolism and its function as an index of oxidative stress. Curr. Med. Chem., 2004, vol. 11, iss. 8, pp. 1041-1064. doi: 10.2174/0929867043455567

38. Li W., Maeda N., Beck M.A. Vitamin C deficiency increases the lung pathology of influenza virus-infected Gulo-/- mice. J. Nutr., 2006, vol. 136, no. 10, pp. 2611-2616.

39. Liang T., Chen X., Su M., Chen H., Lu G., Liang K. Vitamin C exerts beneficial hepatoprotection against Concanavalin A-induced immunological hepatic injury in mice through inhibition of NF- $\mathrm{\kappa B}$ signal pathway. Food Funct., 2014, vol. 5, iss. 9, pp. $2175-2182$. doi: $10.1039 / c 4 f o 00224 e$

40. Lykkesfeldt J., Michels A.J., Frei B. Vitamin C. Adv. Nutr., 2014, vol. 5, pp. 16-18. doi: 10.3945/an.113.005157

41. Meyer M., Pahl H.L., Baeuerle P.A. Regulation of the transcription factors NF-kappa B and AP-1 by redox changes. Chem. Biol. Interact., 1994, vol. 91, no. 2-3, pp. 91-100.

42. Mlkirova N., Hunninghake R. Effect of high dose vitamin C on Epstein-Barr viral infection. Med. Sci. Monit., 2014, vol. 20, pp. 725-732. doi: 10.12659/msm.890423

43. Mohammed B.M., Fisher B.J., Kraskauskas D., Farkas D., Brophy D.F., Fowler A.A., Natarajan R. Vitamin C: a novel regulator of neutrophil extracellular trap formation. Nutrients, 2013, vol. 5, iss. 8, pp. 3131-3151. doi: 10.3390/nu5083131

44. Muller F. Reactive oxygen intermediates and human immunodeficiency virus (HIV) infection. Free Radic. Biol. Med., 1992, vol. 13, iss. 6, pp. 651-657. doi: 10.1016/0891-5849(92)90039-J

45. Noh K., Lim H., Moon S.-K., Kang J.S., Lee W.J., Lee D., Hwang Y.I. Mega-dose Vitamin Cmodulates T cell functions in Balb/c mice only when administered during T cell activation. Immunol. Lett., 2005, vol. 98, no. 1, pp. 63-72. doi: 10.1016/j.imlet.2004.10.012 
46. Padayatty S.J., Katz A., Wang Y., Eck P., Kwon O., Lee J.H., Shenglin C., Corpe C., Dutta A., Dutta S.K., Levine M. Vitamin C as an antioxidant: evaluation of its role in disease prevention. J. Am. Coll. Nutr., 2003, vol. 22, iss. 1, pp. 18-35. doi: 10.1080/0731 5724.2003.10719272

47. Pauling L. Vitamin C and the Common Cold. San Francisco, CA: W.H. Freeman and Company, 1970, $122 p$.

48. Peterhans E. Oxidants and antioxidants in viral diseases: disease mechanisms and metabolic regulation. J. Nutr., 1997, vol. 127, no. 5, pp. 962S-965S.

49. Peterhans E. Sendai virus stimulates chemiluminescence in mouse spleen cells. Biochem. Biophys. Res. Commun., 1979, vol. 91 , pp. 383-392. doi: 10.1016/0006-291X(79)90630-2

50. Peterhans E., Grob M., Burge T., Zanoni R. Virus-induced formation of reactive oxygen intermediates in phagocytic cells. Free Radic. Res. Commun., 1987, vol. 3, iss. 1-5, pp. 39-46. doi: 10.3109/10715768709069768

51. Qiao H., May J.M. Macrophage differentiation increases expression of the ascorbate transporter (SVCT2). Free Radic. Biol. Med., 2009, vol. 46, iss. 8, pp. 1221-1232. doi: 10.1016/j.freeradbiomed.2009.02.004

52. Reshi M.L., Su Y.-C., Hong J.-R. RNA viruses: ROS-mediated cell death. Int. J. Cell. Biol., 2014, 16 p. doi: 10.1155/2014/467452

53. Roederer M., Staal F.J., Raju P.A., Ela S.W., Herzenberg L.A., Herzenberg L.A. Cytokine-stimulated human immunodeficiency virus replication is inhibited by N-acetyl-L-cysteine. Proc. Natl. Acad. Sci. USA, 1990, vol. 87, no. 12, pp. 4884-4888. doi: 10.1073/ pnas.87.12.4884

54. Sasazuki S., Sasaki S., Tsubono Y., Okubo S., Hayashi M., Tsugane S. Effect of vitamin C on common cold: randomized controlled trial. Eur. J. Clin. Nutr., 2006, vol. 60, pp. 9-17. doi: 10.1038/sj.ejcn.1602261

55. Schwarz K.B. Oxidative stress during viral infection: a review. Free Radic. Biol. Med., 1996, vol. 21, iss. 5, pp. 641-649.

56. Shi X., Shi Z., Huang H., Zhu H., Zhou P., Zhu H., Ju P. Ability of recombinant human catalase to suppress inflammation of the murine lung induced by influenza A. Inflammation, 2014, vol. 37, iss. 3, pp. 809-817. doi: 10.1007/s10753-013-9800-2

57. Son E.W., Mo S.J., Rhee D.K., Pyo S. Vitamin C blocks TNF-alpha-induced NF-kappaB activation and ICAM-1 expression in human neuroblastoma cells. Arch. Pharm. Res., 2004, vol. 27, iss. 10: 1073.

58. Tan P.H., Sagoo P., Chan C., Yates J.B., Campbell J., Beutelspacher S.C., Foxwell B.M., Lombardi G., George A.J. Inhibition of NF-kappa B and oxidative pathways in human dendritic cells by antioxidative vitamins generates regulatory T cells. J. Immunol., 2005, vol. 174, iss. 12, pp. 7633-7644. doi: 10.4049/jimmunol.174.12.7633

59. Terezhalmy G.T., Bottomley W.K., Pelleu G.B. The use of water-soluble bioflavonoid-ascorbic acid complex in the treatment of recurrent herpes labialis. Oral Surg. Oral Med. Oral Pathol., 1978, vol. 45, iss. 1, pp. 56-62.

60. Uchide N., Toyoda H. Antioxidant therapy as a potential approach to severe influenza-associated complications. Molecules, 2011, vol. 16, iss. 3, pp. 2032-2052. doi: 10.3390/molecules16032032

61. Wang H., Xu R., Shi Y., Si L., Jiao P., Fan Z., Han X., Wu X., Zhou X., Yu F., Zhang Y., Zhang L., Zhang L., Zhou D., Xiao S. Design, synthesis and biological evaluation of novel L-ascorbic acid-conjugated pentacyclic triterpene derivatives as potential influenza virus entry inhibitors. Eur. J. Med. Chem., 2016, vol. 110, pp. 376-388. doi: 10.1016/j.ejmech.2016.01.005

62. Williams V.M., Filippova M., Soto U., Duerksen-Hughes P.J. HPV-DNA integration and carcinogenesis: putative roles for inflammation and oxidative stress. Future Virol., 2011, vol. 6, no. 1, pp. 45-57. doi: 10.2217/fvl.10.73

63. Wintergerst E.S., Maggini S., Hornig D.H. Immune-enhancing role of vitamin C and zinc and effect on clinical conditions. Ann. Nutr. Metab., 2006, vol. 50, suppl. 2, pp. 85-94. doi: 10.1159/000090495

64. Yuan S. Drugs to cure avian influenza infection-multiple ways to prevent cell death. Cell Death Dis., 2013, 4: e835. doi: 10.1038/ cddis.2013.367

\footnotetext{
Авторы:

Зарубаев В.В., к.б.н., старший научный сотрудник лаборатории экспериментальной вирусологии ФБУН НИИ эпидемиологии и микробиологии им. Пастера,

Санкт-Петербург, Россия;

Слита А.В., к.б.н., старший научный сотрудник лаборатории экспериментальной вирусологии ФБУН НИИ эпидемиологии и микробиологии им. Пастера, Санкт-Петербург, Россия;

Лаврентьева И.Н., д.м.н., зав. лабораторией экспериментальной вирусологии ФБУН НИИ эпидемиологии и микробиологии им. Пастера, Санкт-Петербург, Россия; Смирнов В.С., д.м.н., профессор, главный научный сотрудник ЗАО МБНПК «Цитомед», Санкт-Петербург, Россия.
}

\author{
Authors: \\ Zarubaev V.V., PhD (Biology), Senior Researcher, Laboratory \\ of Experimental Virology, St. Petersburg Pasteur Institute, \\ St. Petersburg, Russian Federation; \\ Slita A.V., PhD (Biology), Senior Researcher, Laboratory \\ of Experimental Virology, St. Petersburg Pasteur Institute, \\ St. Petersburg, Russian Federation; \\ Lavrentieva I.N., PhD, MD (Medicine), Head of the Laboratory \\ of Experimental Virology, St. Petersburg Pasteur Institute, \\ St. Petersburg, Russian Federation; \\ Smirnov V.S., PhD, MD (Medicine), Professor, Head Researcher \\ CJSC MBSIK "Cytomed", St. Petersburg, Russian Federation.
}

